\title{
Density and pond habitat affect survival and growth rates in larval Columbia spotted frogs (Rana luteiventris)
}

\author{
Sidney A. Patchett ${ }^{1}{ }^{*}$, Allystair D. Jones ${ }^{1}$, and Mark C. BelK ${ }^{1}$ \\ ${ }^{1}$ Department of Biology, Brigham Young University, Provo, UT 84602
}

\begin{abstract}
Juvenile survival and growth are critical determinants of evolutionary fitness in most organisms. However, specific effects of population density and habitat quality on survival and growth of larvae vary widely among amphibian species. The Columbia spotted frog (Rana luteiventris), like many amphibians in the arid western United States, is a species of conservation concern, especially in the southern part of its range. To determine how density and habitat affect vital rates of Columbia spotted frog during the larval period, we performed a controlled experiment. Larval growth and survival in the Columbia spotted frog are determined by density of conspecifics and pond habitat. Density of conspecifics is the most important determinant of larval growth, and pond habitat type is the most important determinant of larval survival. Recommendations for repatriation efforts include starting populations with intermediate densities of larvae to optimize the size-versus-number trade-off.
\end{abstract}

RESUMEn.-La supervivencia y el crecimiento de los juveniles son determinantes críticos de la adecuación evolutiva en la mayoría de los organismos. Sin embargo, los efectos específicos de la densidad poblacional y la calidad del hábitat, en la supervivencia y el crecimiento de las larvas varían ampliamente entre las especies de anfibios. La rana, Rana luteiventris, al igual que muchos anfibios del oeste árido de los Estados Unidos, es una especie de preocupación para la conservación, especialmente en la parte sur de su área de su distribución. Para determinar cómo la densidad y el hábitat afectan las tasas vitales de Rana luteiventris durante el período larval, realizamos un experimento controlado. El crecimiento y la supervivencia larval de Rana luteiventris dependen de la densidad de coespecíficos y el hábitat del estanque. El tipo de hábitat del estanque es el factor más importante para la supervivencia de las larvas, mientras que la densidad de coespecíficos es el agente más importante para el crecimiento de las larvas. Las recomendaciones para los esfuerzos de repatriación incluyen iniciar con poblaciones de larvas de densidades intermedias para optimizar el equilibrio entre el tamaño y el número.

Juvenile survival and growth are critical determinants of evolutionary fitness in most organisms (Berven and Gill 1983, Beck and Congdon 2000, Biek et al. 2002). In organisms with indeterminate somatic growth, size at metamorphosis and size at maturity (consequences of juvenile growth rate) are strong predictors of reproductive success (Semlitsch et al. 1988). In addition, juveniles of most organisms characteristically exhibit high mortality rates (Brockelman 1975, Promislow and Harvey 1990) such that even relatively small changes in juvenile mortality rate translate into large effects on fitness (Mangel and Stamps 2001, Patrick et al. 2008). Juvenile survival and growth often covary depending on the relative intensity of density-dependent and density-independent effects (Scott 1994,
Reaser 2000, Altwegg and Reyer 2003). Thus, fitness during the juvenile period is determined by the nature of the interaction between survival and growth.

Population density and habitat quality are especially strong predictors of juvenile survival and growth in larval amphibians (Beebee et al. 1996, Chelgren et al. 2006). However, specific effects of density and habitat quality on survival and growth of larvae vary widely among amphibian species (Schaffer 1974, Richter-Boix et al. 2011, Earl and Semlitsch 2013, Ding et al. 2015). For example, larval survival and size at metamorphosis are both negatively correlated with clutch density in many amphibian species, but the slope of these relationships varies among species (Berven 1990, Hels and Nachman 2002).

*Corresponding author: sidneypatchett@gmail.com 
Common toads (Bufo bufo) are highly affected by larval densities, and individuals from lowdensity clutches regularly outperform those from high-density clutches in physical endurance (Goater et al. 1993). In water frogs (Rana lessonae and $R$. esculenta), early metamorphosis and increased size positively affect postmetamorphic fitness, but larval density appears to have little effect on timing of or size at metamorphosis (Altwegg and Reyer 2003). Neotropical red-eyed tree frogs (Agalychnis callidryas) grow larger and have higher rates of survival at low densities, but the larger frogs grow at a slower rate after metamorphosis than frogs at high densities (Tarvin et al. 2015). Metamorphosis rate decreases as larval density increases and metamorphosis time increases as food availability decreases in the Chinese tiger frog (Hoplobatrachus rugulosa; Ding et al. 2015). For some amphibians, the presence of pollution as a component of habitat quality can reduce the positive effects of low population density (Sanzo and Hecnar 2006, Ortiz-Santaliestra et al. 2012). Because of the interactive effects of density and habitat quality, it is difficult to generalize among species about the relative effects of these 2 factors on larval survival and growth. Thus species-specific, and possibly site-specific, information is required to determine vital rates in larval amphibians.

The Columbia spotted frog (Rana luteiventris), like many amphibians in the arid western USA, is a species of conservation concern, especially in the southern part of its range (Green et al. 1996). Combinations of chytrid fungus disease (Collins and Storfer 2003, Weldon et al. 2004, Lips et. al. 2006, Kilpatrick et al. 2010), habitat loss (Stuart et al. 2004), introduced predators, and effects of climate change make conservation of Columbia spotted frogs difficult (Reaser and Pilliod 2000). Population persistence is critically dependent on survival and growth during the larval period. Although population dynamics and status (Hovingh 1993, Reaser 2000, Funk et al. 2005), impacts of climate change (Pilliod et al. 2015), and habitat quality (Bull 2003) have been studied in Columbia spotted frogs, the effects of population density and habitat quality on larval survival and growth have not been experimentally documented.

To determine how density and habitat affect vital rates of the Columbia spotted frog during the larval period we evaluated the effects of starting density and pond habitat on survival and growth of larval frogs. In addition, we evaluated the effect of ending density on size at metamorphosis.

\section{METHODS}

\section{Columbia Spotted Frog Natural History}

The Columbia spotted frog (Rana luteiventris) is found throughout the northwestern portion of North America, extending from Alaska through Canada, Washington, Idaho, Wyoming, Montana, and fragmented portions of Nevada and Utah. (Green et al. 1996, Reaser and Pilliod 2000). Isolated, relict populations occur in the southern portion of this range. Relict populations of the Columbia spotted frog along the Wasatch Front in Utah are found in wetland habitats with low water flow rates, little shade, and cool, clear water (Green et al. 1996, 1997). In Utah, Columbia spotted frogs emerge and reproduce in mid-March when air temperatures reach $13{ }^{\circ} \mathrm{C}$ to $26{ }^{\circ} \mathrm{C}$ (Turner 1960, Morris and Tanner 1969, Reaser and Pilliod 2000). Once ubiquitous in wetlands throughout northern Utah, viable populations now exist only in isolated springheads in the West Desert and along the Wasatch Front. The reduced distribution of the Columbia spotted frog in Utah in recent decades is associated with urbanization and water development (Green et al. 1997, Reaser and Pilliod 2000).

\section{Study Site}

We performed this experiment at the Swaner Nature Preserve (SNP; $40.7015^{\circ} \mathrm{N}$ $\left.111.5191^{\circ} \mathrm{W}\right)$, a private trust covering about 425 ha in the Snyderville Basin of Summit County, Utah, USA. Within the larger preserve is a Wetlands Reserve Program permanent conservation easement of 216 ha held by the Natural Resources Conservation Services. Conservation efforts in years just prior to the experiment focused on protecting the upper watershed of East Canyon Creek, filling in diversion ditches and channels, replanting native vegetation, and enhancing 3 ponds that were intended to provide habitat for Columbia spotted frogs. Enhancement of these ponds occurred in fall of 2003 in accordance with specifications given by Utah Department of Wildlife Resources. The ponds were approximately $15-20 \mathrm{~m}$ in diameter, $1.5 \mathrm{~m}$ in depth, 
and graded on the northwestern side to provide shallows for oviposition. Ponds are spring fed, and the entire area remains relatively wet even during drought conditions. The chorus frog (Pseudacris triseriata) is the only other frog species known to occur in the preserve. These ponds in the Swaner Nature Preserve were identified as a priority site for repatriation of the Columbia spotted frog.

\section{Experimental Procedure}

To determine the effects of starting density and pond habitat on survival and growth (i.e., size at metamorphosis), we ran an experiment as part of the repatriation effort at the Swaner Nature Preserve. On 14 April 2004, we gathered eggs from a population located along the Provo River corridor below the Jordanelle Reservoir dam. This source population was geographically closest to the repatriation site; the source site was ecologically and environmentally similar to the repatriation site; and the source population of Columbia spotted frog was relatively large and robust. We used larvae from 15 clutches of eggs. Each clutch was separated into 2 approximately equal masses, and half of each clutch was left in place, while the other halves were placed in plastic containers and transported to the Brigham Young University campus. Egg masses were then placed outdoors in a $1100-\mathrm{L}$ plastic tub containing aged tap water with constant aeration until hatching.

We installed cages in the 3 ponds at Swaner Nature Preserve, arbitrarily named A, B, and C. Pond C was stream-fed with both an inflow and outflow; however, the shallow area created for spawning was to the side of the main flow. Ponds A and B were connected to groundwater, but had no flowing connections. Ponds $\mathrm{A}$ and $\mathrm{C}$ had some emergent aquatic vegetation, but Pond B had none. Thus, each pond represented a somewhat different combination of habitats, and we treated each pond as a unique environment or habitat type in our analysis. Cages were constructed using PVC frames to support mesh screening $(1.5 \mathrm{~mm}$ mesh) designed to enclose one square meter of pond surface area $(1 \mathrm{~m} \times 1 \mathrm{~m} \times 0.5 \mathrm{~m}$ high). Each open-bottom cage was pushed into the substrate and secured to fence posts with cable ties. Any gaps around the bottom perimeter were filled in with mud from the pond. Eight cages were placed in ponds A and $\mathrm{B}$, and 16 cages were placed in the larger pond $\mathrm{C}$.

On 3 May 2004, after eggs had hatched, we collected the tadpoles. Tadpoles were separated from any remnants of jelly coats or other debris and rinsed several times with clean water to reduce the likelihood of introducing novel pathogens to the repatriation site (e.g., chytrid fungus). Tadpoles from all clutches were then combined, placed in several large coolers, and transported to Swaner Nature Preserve. Groups of 25, 50, 75, or 100 tadpoles were taken haphazardly from the cooler and assigned to each cage according to a randomized block design. Tadpoles were generally healthy and uniform in size, but any listless, injured, or noticeably larger or smaller animals were excluded. Ponds A and B each contained 2 complete sets of the 4 density treatments (i.e., 25, 50, 75, and 100), whereas pond $\mathrm{C}$ contained 4 sets, yielding 8 total replicates of each of the 4 density treatments. After stocking tadpoles, we covered the top of each cage with 15-mm plastic mesh to deter larger predators. Throughout the growing season, cages were monitored and all tadpoles were fed a supplemental diet of ground spinach 3 times per week. Each cage initially received about $1.7 \mathrm{~g}$ of ground spinach per 25 tadpoles per feeding, and this amount was doubled on 21 June to accommodate the increased size of tadpoles.

We placed a floating cork platform $(30 \times$ $30 \mathrm{~cm}$ ) in each cage to provide a resting place for newly metamorphosed individuals. When it appeared that most larvae had metamorphosed we ended the experiment. To remove the frogs from the cages we used a successive removal depletion method. Frogs were removed from the cages through dip netting in 4 successive timed efforts, lasting one minute each. Frogs were rarely caught on the third depletion effort, and never on the fourth, thus we are confident nearly all surviving individuals were captured. Each frog was measured for snout-vent length (SVL), weighed to the nearest $0.1 \mathrm{~g}$, and categorized with respect to metamorphosis. All experimental individuals were released into their respective ponds after measurements were completed.

\section{Statistical Analysis}

Survival was measured as the number of individuals found alive at metamorphosis 
TABLE 1. Analysis of variance (ANOVA) table for percent survival and size at metamorphosis for the density experiment. Significant $P$ values are bolded.

\begin{tabular}{|c|c|c|c|c|}
\hline Response variable & Source & $\mathrm{df}$ & $F$ & $P$ \\
\hline \multirow[t]{3}{*}{ Percent survival } & Pond & 2,19 & 191.35 & $<0.0001$ \\
\hline & Start Density & 3,19 & 5.09 & 0.0094 \\
\hline & Pond * Start Density & 6,19 & 4.03 & 0.0090 \\
\hline \multirow[t]{4}{*}{ Mass at metamorphosis } & Pond & $2,13.2$ & 39.35 & $<0.0001$ \\
\hline & Start Density & $3,13.3$ & 8.92 & 0.0017 \\
\hline & Pond * Start Density & $6,12.9$ & 7.26 & 0.0015 \\
\hline & Ending Density & $1,23.3$ & 85.83 & $<0.0001$ \\
\hline
\end{tabular}

compared to the starting number of individuals in the cage (the response variable), so effects of density and pond habitat quality were analyzed with a logistic regression approach with a logit link function (Proc GENMOD in SAS v. 9.3; SAS Institute Inc., Cary, NC). Starting density and pond (A, B, or $\mathrm{C}$ ) were used as predictor variables and the 2-way interaction between density and pond was included. For size at metamorphosis (mass), effects of density and pond habitat quality were analyzed with a mixed-model analysis of variance approach (Proc MIXED in SAS v. 9.3; SAS Institute Inc., Cary, NC). Size at metamorphosis was natural-log transformed, based on visual inspection of residual plots, to meet the assumption of normal distribution of residuals. Starting density and pond $(\mathrm{A}, \mathrm{B}$, or $\mathrm{C})$ were used as predictor variables and the 2-way interaction between density and pond was included. Cage was included in the model as a random effect. Finally, to explore the potential interaction between survival and growth in the Columbia spotted frog, we used regression analysis of number surviving (i.e., ending density) on growth rate. Number of frogs surviving the larval period is a function of the starting density and the survival rate. The response variable was size (mass) at metamorphosis and the predictor variable was number of frogs per cage at the end of the experiment. Similar to the previous analysis on size at metamorphosis, we included cage as a random effect and used Proc MIXED in SAS (v. 9.3; SAS Institute Inc., Cary, NC) for the analysis.

\section{REsults}

Larvae in pond B metamorphosed earliest (late July) followed closely by those in pond A (early August). Larvae in pond C metamorphosed about one month later in late August. Percent survival differed significantly by density, pond, and the pond-by-density interaction (Table 1). Percent survival was high in pond B (86\% to $92 \%)$ and extremely low in pond $\mathrm{C}$ (4\% to $15 \%$ ) but constant across all starting densities within these 2 ponds. In contrast, percent survival was moderate in pond $\mathrm{A}$ at the first 3 starting densities $(44 \%$ to $60 \%)$, but was extremely low in those cages with starting densities of 100 (12\%; Fig. 1). The wide variance in survival among density treatments in pond A compared to the relatively constant effect of density in the other 2 ponds accounts for the significant interaction term in the analysis.

Mass at metamorphosis was significantly affected by density, pond, and the pond-bydensity interaction (Table 1). Mass at metamorphosis was highest in ponds $\mathrm{A}$ and $\mathrm{C}$ and lowest in pond $\mathrm{B}$. Highest mass at metamorphosis was found at the 2 lowest starting densities (25 and 50). The significant interaction between pond and density was caused by the variation in survival among ponds such that differences in starting density were not maintained in ponds A and C (Fig. 2).

Survival rate and starting density caused differences in densities experienced throughout the experiment such that size at metamorphosis was significantly negatively related to density at the end of the experiment (Table 1; regression equation: Log size at metamorphosis $=-0.0139 *$ Ending Density +0.48$)$. Low densities of about 30 or fewer individuals per cage resulted in size at metamorphosis about 3 times greater (mass at metamorphosis about $1.5 \mathrm{~g}$ ) than size at metamorphosis in cages that had greater than 80 individuals surviving (mass at metamorphosis about $0.5 \mathrm{~g}$ ).

\section{Discussion}

The results of the experiment display a predictable relationship between larval density 


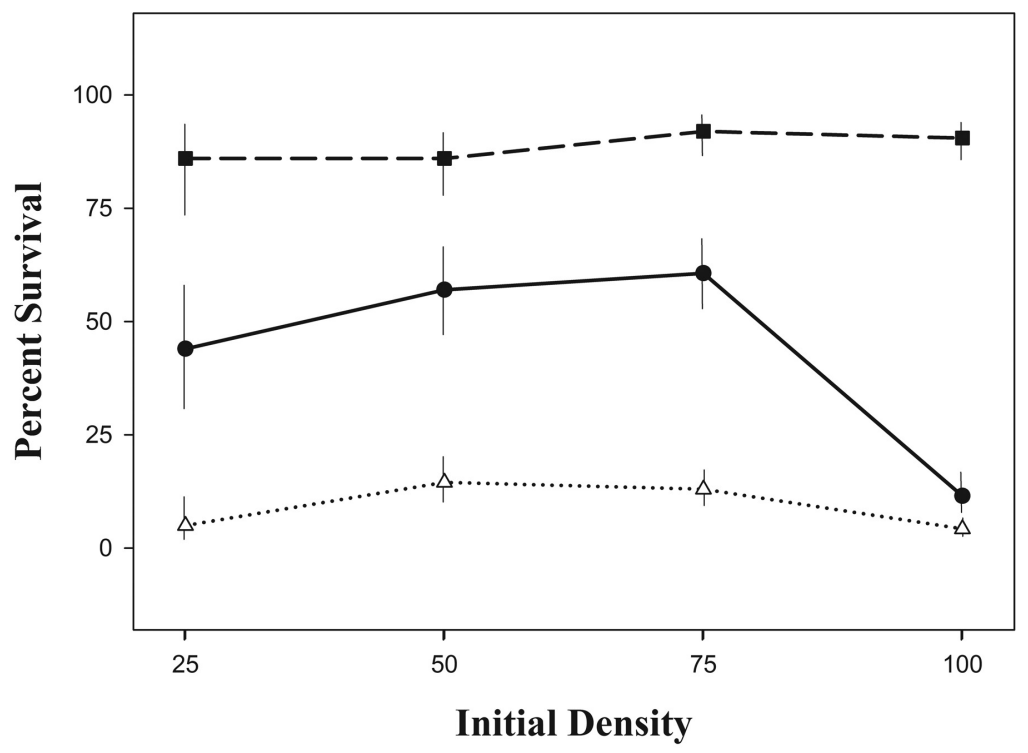

Fig. 1. Mean percent surviving per cage of Columbia spotted frog by density. Bars indicate $95 \%$ confidence intervals. Closed circle/solid line indicates pond A, closed square/long dash indicates pond B, and open triangle/short dash indicates pond $\mathrm{C}$.

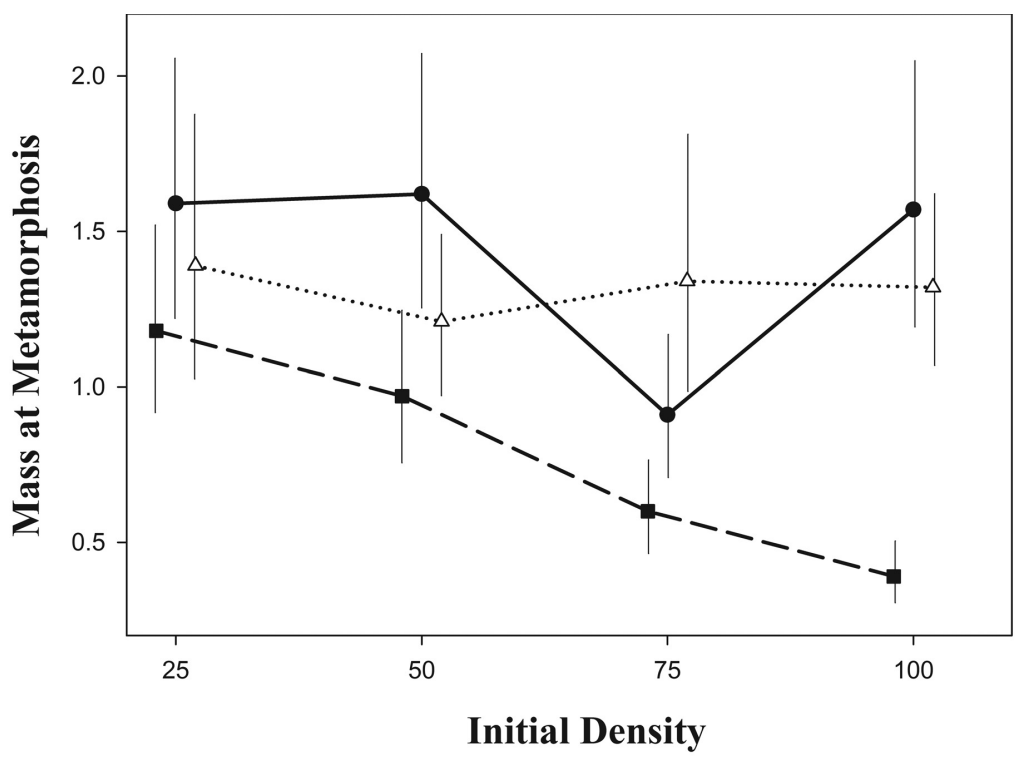

Fig. 2. Mean mass of Columbia spotted frog at metamorphosis (natural-log transformed, in mg) by initial density. Bars indicate $95 \%$ confidence intervals. Closed circle/solid line indicates pond A, closed square/long dash indicates pond B, and open triangle/short dash indicates pond C. Symbols are offset for clarity.

and habitat quality on larval growth and survival of the Columbia spotted frog. Pond habitat exhibited strong effects on survival. Survival in other larval amphibians has been related to habitat quality, and less so to larval density
(Wilbur 1976, Horne and Dunson 1995, Boone 2005, Richter-Boix et al. 2011). Variation in survival and the resulting population densities strongly affected growth rates as evidenced by size at metamorphosis. Low mortality in some 
ponds resulted in high densities and low growth rates, and high mortality in other ponds resulted in low density and high growth rates. These results from the Columbia spotted frog are qualitatively similar to numerous studies on growth and survival of larval amphibians where variation in intraspecific competition (i.e., density effects) determines growth rates. (Wilbur 1977, Scott 1990, Goater 1994, Rowe and Dunson 1995, Ding et al. 2015, Tarvin et al. 2015). By choosing habitats for oviposition, females are balancing effects on survival and subsequent effects on growth. The fitness payoff for a particular choice depends on the behavior of other individuals and on variation in the environment through space and time. Large body size at metamorphosis may be important in some locations and at some times, but the fitness advantage of large body size may not be constant among all habitats and at all times (Blanckenhorn 2000, Tarvin et al. 2015). Thus, this trade-off between survival and corresponding density-dependent growth rates may help maintain high levels of variation in habitat selection within the population.

Population dynamics of larval Columbia spotted frogs are a product of the number of offspring surviving (mainly influenced by pond habitat quality) and the size at metamorphosis or quality of larvae (mainly influenced by density). Thus, this relationship can inform best practices for repatriation efforts. Determining optimal starting densities for repatriation "head-start" enclosures represents the same evolutionary trade-off as that faced by female frogs at oviposition. The optimal solution is neither maximization of starting numbers (at the expense of body size), nor maximization of size at metamorphosis (at the expense of numbers) (see also Ding et al. 2015). Rather, optimization of the size-number tradeoff as occurs at intermediate densities mimics the evolutionary solution to the tradeoff. In most amphibians, success in the terrestrial environment depends on size at metamorphosis, which is a product of density in the larval environment (Wilbur 1976). However, some amphibian species have shown positive results in overcoming low larval growth when introduced to an optimum terrestrial environment (Boone 2005). Repatriation sites will not be inhabited with populations of potential competitors, and thus may provide Columbia spotted frogs with a suitable habitat to overcome low metamorphic size. This might suggest that populations should be started with large numbers (i.e., high densities) and that corresponding small size at metamorphosis might be overcome during the terrestrial stage. However, it seems unlikely that low size at metamorphosis can be completely overcome during the adult stage (Auld et al. 2010). On the other hand, in expanding populations that are far from carrying capacity, size and corresponding fecundity at first reproduction are the most important determinants of population growth. After only a few generations, the effect of increasing fecundity outweighs the effect of increasing the starting number of individuals. The size-number tradeoff evidenced in this study suggests that it is prudent to start new populations at intermediate densities (in the range used in this study). This should result in the most rapid population growth for new populations.

In summary, larval growth and survival in the Columbia spotted frog in this experiment were determined by density of conspecifics and pond habitat quality. Pond habitat type was the most important determinant of larval survival, and density of conspecifics was the most important determinant of larval growth. Recommendations for repatriation efforts include starting populations in small ponds with suitable habitat and using intermediate densities of larvae to optimize the size-versusnumber tradeoff.

\section{ACKNOWLEDGMENTS}

Funding and collection permits for this project were provided by the Utah Division of Wildlife Resources. All experimental protocols were approved by the Institutional Animal Care and Use Committee at Brigham Young University. We thank Erik Harvey for his oversight of the field experiment and acknowledge the participation and help of numerous BYU undergraduates in the fieldwork. We appreciate the cooperation and help of individuals from the Utah Division of Wildlife Resources, the Utah Reclamation, Mitigation, and Conservation Commission, and the Swaner Nature Preserve.

\section{LITERATURE CITED}

AltwegG, R., And H.U. Reyer. 2003. Patterns of natural selection on size at metamorphosis in water frogs. Evolution 57:872-882. 
Auld, J.R., A.A. Agrawal, and R.A. Relyea. 2010. Reevaluating the costs and limits of adaptive phenotypic plasticity. Proceedings of the Royal Society of London B 277:503-511.

Beck, C.W., AND J.D. Congdon. 2000. Effects of age and size at metamorphosis on performance and metabolic rates of southern toad, Bufo terrestris, metamorphs. Functional Ecology 14:32-38.

Beebee, T.J.C., J.S. Denton, And J. Buckley. 1996. Factors affecting population densities of adult natterjack toads (Bufo calamita) in Britain. Journal of Applied Ecology 33:263-268.

Berven, K.A. 1990. Factors affecting population fluctuations in larval and adult stages of the wood frog (Rana sylvatica). Ecology 71:1599-1608.

Berven, K.A., AND D.E. GILL. 1983. Interpreting geographic variation in life-history traits. American Zoologist 23:85-97.

Biek, R., W.C. FunK, B.A. MaXell, And L.S. Mills. 2002. What is missing in amphibian decline research: insights from ecological sensitivity analysis. Conservation Biology 16:728-734.

Blanckenhorn, W.U. 2000. The evolution of body size: what keeps organisms small? Quarterly Review of Biology 75:385-407.

Boone, M.D. 2005. Juvenile frogs compensate for small metamorph size with terrestrial growth: overcoming the effects of larval density and insecticide exposure. Journal of Herpetology 39:416-423.

Brockelman, W.Y. 1975. Competition, the fitness of offspring, and optimal clutch size. American Naturalist 109:677-699.

BulL, E.L. 2003. Diet and prey availability of Columbia spotted frogs in northeastern Oregon. Northwestern Science 77:349-356.

Chelgren, N., D. Rosenberg, S. Heppell, and A. GitelMAN. 2006. Carryover aquatic effects on survival of metamorphic frogs during pond emigration. Ecological Applications 16:250-261.

Collins, J.P., AND A. Storfer. 2003. Global amphibian declines: sorting the hypotheses. Diversity and Distributions 9:89-98.

Ding, G.H., Z.H. LIN, X.L. FAN, AND X. JI. 2015. The combined effects of food supply and larval density on survival, growth and metamorphosis of Chinese tiger frog (Hoplobatrachus rugulosa) tadpoles. Aquaculture 435:398-402.

Earl, J.E., AND R.D. SEmLitsch. 2013. Carryover effects in amphibians: are characteristics of the larval habitat needed to predict juvenile survival? Ecological Applications 23:1429-1442.

Funk, W.C., M.S. Blouin, P.S. Corn, B.A. Maxell, D.S. Pilliod, S. Amish, and F.W. Allendorf. 2005. Population structure of Columbia spotted frogs (Rana luteiventris) is strongly affected by the landscape. Molecular Ecology 14:483-496.

GoATER, C.P. 1994. Growth and survival of postmetamorphic toads: interactions among larval history, density, and parasitism. Ecology 75:2264-2274.

Goater, C.P., R.D. Semlitsch, and M.V. Bernasconi. 1993. Effects of body size and parasite infection on the locomotory performance of juvenile toads, Bufo bufo. Oikos 66:129-136.

Green, D.M., H. Kaiser, T.F. Sharbel, J. Kearsley, and K.R. MCAllister. 1997. Cryptic species of spotted frogs, Rana pretiosa complex, in western North America. Copeia 1997(1):1-8.
Green, D.M., T.F. Sharbel, J. Kearsley, and H. Kaiser. 1996. Postglacial range fluctuation, genetic subdivision and speciation in the western North American spotted frog complex, Rana pretiosa. Evolution 50:374-390.

Hels, T., AND G. NACHMAN. 2002. Simulating viability of a spadefoot toad Pelobates fuscus metapopulation in a landscape fragmented by a road. Ecography 25: $730-744$.

Horne, M.T., And W.A. Dunson. 1995. Effects of low pH, metals and water hardness on larval amphibians. Archives of Environmental Contamination and Toxicology 29:500-505.

Hovingh, P. 1993. Aquatic habitats, life history observations, and zoogeographic considerations of the spotted frog (Rana pretiosa) in Tule Valley, Utah. Great Basin Naturalist 53:168-179.

Kilpatrick, A.M., C.J. Briggs, and P. Daszak. 2010. The ecology and impact of chytridiomycosis: an emerging disease of amphibians. Trends in Ecology and Evolution 25:109-118.

Lips, K.R., F. Brem, R. Brenes, J.D. Reeve, R.A. Alford, J. Voyles, C. Carey, L. Livo, A.P. Pessier, and J.P. ColLins. 2006. Emerging infectious disease and the loss of biodiversity in a Neotropical amphibian community. Proceedings of the National Academy of Sciences of the United States of America 103: 3165-3170.

Mangel, M., And J. Stamps. 2001. Trade-offs between growth and mortality and the maintenance of individual variation in growth. Evolutionary Ecology Research 3:583-593.

Morris, R.L., AND W.W. Tanner. 1969. The ecology of the western spotted frog Rana pretiosa pretiosa Baird and Girard, a life history study. Great Basin Naturalist 29:45-81.

Ortiz-Santaliestra, M.E., M.J. Fernández-Benéitez, AND A. MarCo. 2012. Density effects on ammonium nitrate toxicity on amphibians: survival, growth and cannibalism. Aquatic Toxicology 110-111:170-176.

Patrick, D.A., E.B. Harper, M.L.J. Hunter, and A.J.K. Calhoun. 2008. Terrestrial habitat selection and strong density-dependent mortality in recently metamorphosed amphibians. Ecology 89:2563-2574.

Pilliod, D.S., R.S. Arkle, J.M. Robertson, M.A. Murphy, AND W.C. FUnK. 2015. Effects of changing climate on aquatic habitat and connectivity for remnant populations of a wide-ranging frog species in an arid landscape. Ecology and Evolution 5:3979-3994.

Promislow, D.E., AND P.H. Harvey. 1990. Living fast and dying young: a comparative analysis of life-history variation among mammals. Journal of Zoology 220: $417-437$.

REASER, J.K. 2000. Demographic analysis of the Columbia spotted frog (Rana luteiventris): case study in spatiotemporal variation. Canadian Journal of Zoology 78:1158-1167.

Reaser, J.K., AND D.S. Pilliod. 2000. Columbia spotted frog (Rana luteiventris). Status and trends of North American amphibians. Smithsonian Institution Press, Washington, DC.

Richter-Boix, A., M. Tejedo, and E.L. Rezende. 2011. Evolution and plasticity of anuran larval development in response to desiccation: a comparative analysis. Ecology and Evolution 1:15-25.

Rowe, C.L., AND W.A. Dunson. 1995. Impacts of hydroperiod on growth and survival of larval amphibians 
in temporary ponds of central Pennsylvania, USA. Oecologia 102:397-403.

Sanzo, D., AND S.J. Hecnar. 2006. Effects of road de-icing salt $(\mathrm{NaCl})$ on larval wood frogs (Rana sylvatica). Environmental Pollution 140:247-256.

SCHAFFER, W.M. 1974. Selection for optimal life histories: the effects of age structure. Ecology 55:291-303.

SCOTT, D.E. 1990. Effects of larval density in Ambystoma opacum: an experiment large-scale field enclosures. Ecology 71:296-306.

ScotT, D.E. 1994. The effect of larval density on adult demographic traits in Ambystoma opacum. Ecology 75:1383-1396.

Semlitsch, R.D., D.E. ScotT, and J.H. Pechmann. 1988. Time and size at metamorphosis related to adult fitness in Ambystoma talpoideum. Ecology 69:184-192.

Stuart, S.N., J.S. Chanson, N.A. Cox, B.E. Young, A.S.L. Rodrigues, D.L. Fichman, and R.W. WaLLER. 2004. Status and trends of amphibian declines and extinctions worldwide. Science 306:1783-1786.

Tarvin, R.D., C.S. Bermudez, V.S. Briggs, and K.M. WARKENTIN. 2015. Carry-over effects of size at meta- morphosis in red-eyed treefrogs: higher survival but slower growth of larger metamorphs. Biotropica 47: 218-226

TURnER, F.B. 1960. Life history of the western spotted frog in Yellowstone Park, Wyoming. Ecological Monographs 30:251-278.

Weldon, C., L.H. du Preez, A.D. Hyatt, R. Muller, and R. SPEARE. 2004. Origin of the amphibian chytrid fungus. Emerging Infectious Diseases 10:2100-2105.

Wilbur, H.M. 1976. Density-dependent aspects of metamorphosis in Ambystoma and Rana sylvatica. Ecology 57:1289-1296.

Wilbur, H.M. 1977. Density-dependent aspects of growth and metamorphosis in Bufo americanus. Ecology $58: 196-200$.

Received 16 February 2018

Accepted 14 March 2018

Published online 26 June 2018 